\title{
Coconut planting in Ben Tre is a culture that responds to the natural environment and responds to climate change from a cultural ecological perspective
}

\author{
Ngô Hoàng Đại Long ${ }^{1}$ *
}

\section{Summary}

Coconut farming in Ben Tre plays a very important role, creating unique features of the province's culture and economy. In the land of Coconut - Ben Tre in particular as well as in the sweet "phu sa" sub-region in general, for the first time the work of coconut cultivation has become a profession, that is the profession of coconut farming. It is this profession that has created so many livelihoods for the people at the same time, it also helps us to recognize the nuances of "hard-working civilization" that have a very specific characteristic for the resident community in this land.

In the context of climate change today, people must "save themselves" by offering initiatives (folk experience) to adapt, mitigate risks that may occur to themselves., family and community before outside intervention. The following article of the research team will contribute to clarify the cultural values that deal with the natural environment and adapt to climate change from the ecological ecological culture inherited from coconut plantation. back to local.

Key words: coconut plantation, climate change, Ben Tre, Xu Dua, cultural ecology

\section{Geographical characteristics and distribution of coconut growing areas in Ben Tre}

Ben Tre is a province downstream of the Mekong River, made up of three islets such as An Hoa, Bao and Minh. Looking at the map, Ben Tre province has a fan shape, but the tip is located upstream of large tributaries, like a fan spreading to the east. The natural area of the province is $2.315,01 \mathrm{~km}^{2}$, the north by Tien Giang province, has common boundary is "the Tien River (sông Tiền)", west and south of Vinh Long and Tra Vinh province, there is the common boundary of Co Chien river (sông Cổ Chiên), the East Sea borders with the coastline of $65 \mathrm{~km}$. About administrative boundaries: Ben Tre has 09 affiliated units including Ben Tre city, Chau Thanh district, Cho Lach, Mo Cay Nam, Mo Cay Bac, Giong Trom, Binh Dai, Ba Tri and Thanh Phu. The total population of the province is nearly 1.3 million people (2012), with ethnic minorities: Kinh majority accounts for $99.88 \%$, Chinese $0.11 \%$, Khmer $0.11 \%$ [Ben Tre People's Committee, 2013].

"Xu Dua" - nick name of Ben Tre has four sides surrounded by rivers, the land has a very dense waterway system including large rivers connecting from the East Sea through the main estuaries ("Cua Dai", "Cua Tieu", "Ham Luong" and "Co Chien" estuaries), in the upstream direction of the Mekong River (sông Mê Kong) and an interlocking system of canals and ditches like vein running through three islets so it is very convenient for transportation and irrigation. as well as agriculture.

\footnotetext{
${ }^{1}$ Researcher, Seas \& Island Research Center - Ho Chi Minh City University of Social Sciences and Humanities HCM *Articles participating in the subject International Workshop: "Vietnam Coconut: Value and Potential" (2014)
} 
The growth of coconut trees depends on two factors: climate and soil. In general, in Ben Tre the conditions of temperature $\left(19-27{ }^{\circ} \mathrm{C}\right)$, humidity $(70-85 \%)$, rainfall $(1,000-2,300 \mathrm{~mm})$, light (5-8 hours/day) and especially characteristics of sandy loamy soil with good drainage are suitable for the growth and development of coconut trees here [9].
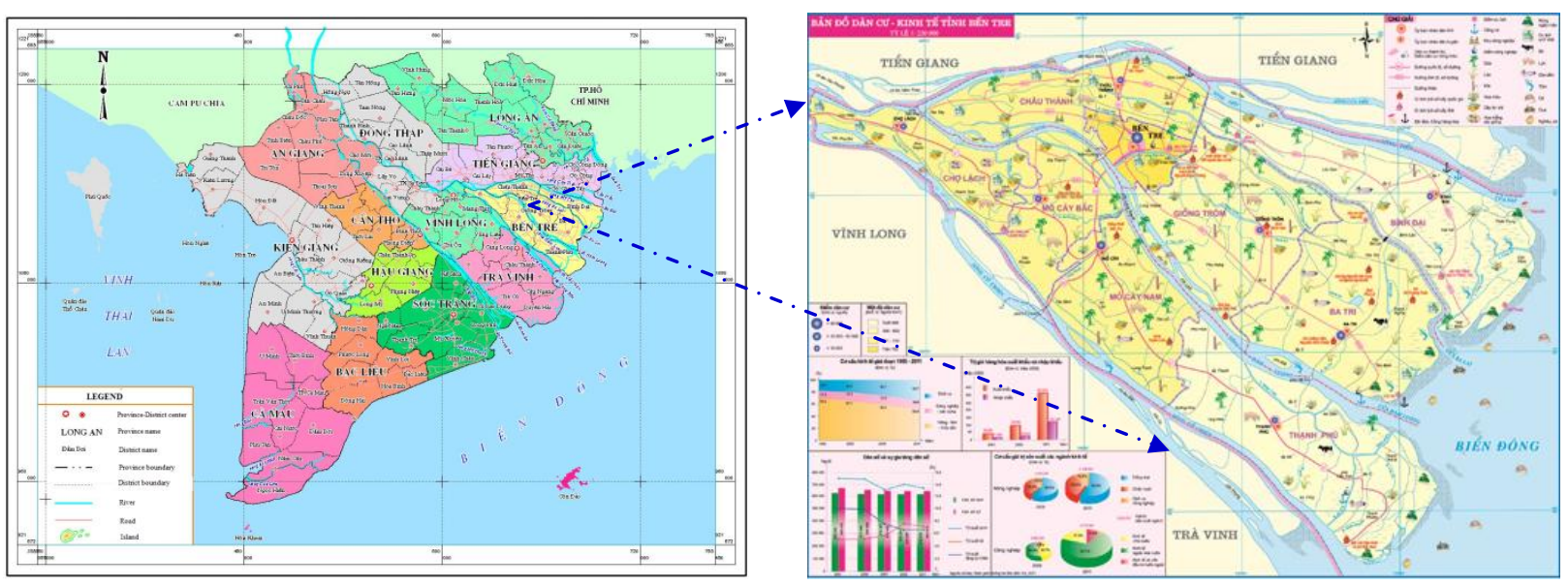

Figure 1. Ben Tre area and coconut growing areas

Coconut is a perennial crop (industrial tree), which plays an important role in Ben Tre's cropping system. Coconut trees and coconut production and processing activities have created a special economic, cultural, social and ecological environment in the lower Mekong region. That appearance is constantly changing and associated with the history of formation and development of Ben Tre coconut.

The country currently has about 200,000 hectares of coconut plantation, Ben Tre is the leading province on both sides: the area and production are concentrated into a large material area with more than 58,440 hectares (in 2012), accounting for $31 \%$ of agricultural land. of the province and account for $38.8 \%$ of the country's coconut area, of which $87.5 \%$ is coconut for rice for industrial processing; the rest are coconut water. Ben Tre coconut productivity is in the highest group (9,703 fruits/ha/year). Coconut production is more than 469 million fruits (2012). The whole province has 163,082 households planting coconut, the majority of households planted coconut has a small land area (of which, 122,964 households planted less than 0.5 ha, 31,652 households planted from 0.5 to 1 ha and 8,466 households planted on 1 ha). (Source: Report of Ben Tre People's Committee on the Program on development of coconut industry in Ben Tre province till 2020).

Ben Tre is the cluster islands, dunes and "island estuary" is last of the Mekong should receive nh Article sediment before flowing into the sea east of the interaction between the sea and the river, so that tree green coconut better, higher productivity than other regions. Three districts with large coconut areas in Ben Tre are Giong Trom, Chau Thanh and Mo Cay (when not yet separated from the district, now Mo Cay Nam and Mo Cay Bac). Regions Ba Tri, Thanh Phu, Binh Dai and although coconut production area and not by the remaining districts in the province. However, coconuts still grow well in mounds, sandy soils with salinity below 10 (\%), without being flooded and constantly saline. 


\section{Cultural ecology in the behavior of people living downstream of the Mekong River - the land of coconut in Ben Tre}

Following the theory of "cultural ecology" (cultural ecology) ${ }^{2}$, the more rudimentary a person is in the life of a society, the more dependent it is on society as opposed to the communes The association has a high level of technical development. J.H.Steward who proposed this theory analyzes the interaction between the natural environment and the cultural environment, people must adapt to survive, in the context of that natural ecology, humans must experience and create. culture and living skills of the community based on the psychology and cultural identity of their people. From the cultural achievements gained through the process of adapting to the ecological environment, people have formed distinctive cultural nuances [Steward, 1995, 82].

According to research on human adaptation to the natural and social environment [Joralemon, 2010, p. 165]. Human adaptations mentioned here include biological and cultural processes that allow a limited number of populations to exist and reproduce within a defined environment or to change their environment school live. Also author J.H.Steward [3], cultural ecology is the way in which cultural transformation processes created by adaptation to the environment, are approached through the following 3 points: i) Set of effective use of methods and practices technology to benefit from it. ii) Explore patterns of human behavior / culture in order to adapt and survive with the environment. iii) Determine how the values of behavioral patterns affect the appearance of culture. [Steward, 1995, p.34]

So ecology-cultural status as ethnic adaptation process with the surrounding natural environment, together with the social environment. The cultural ecology of a ethnic group is also the awareness of the worldview, the mode of production, the mode of living, social structure, religious beliefs, customs and traditions... So, the land Ben Tre has high coastal fields, islets, high strips of land that are permanent settlements for the first class of community residents to come to this land. In the process of living with nature, they take advantage of the special land and soil of this area to create coconut cultivation with distinct cultural nuances. They gradually separated from their traditional farming practices (planting rice) to gardening because the high land is more suitable for fruit trees, in which coconut is one of the pioneer trees that contribute to the transformation of tree structure grow.

In the process of coping with nature and taking advantage of land, there has been a change of awareness leading to changes in actions and lifestyles of Ben Tre people. As far as getting Tran Ngoc Them: "In the South West - the first time the garden separated from the field, to be exploited on a large scale, mainly the scope of subregional p scare sa sweet (with gardens and contempt isles by the folk name). For the first time, there was a separate career separated from agriculture - that was horticulture, together with its own experiences, techniques and achievements, creating what Son Nam called gardening civilization". [Tran Ngoc Them, 2013, p. 393] [4].

"Production labor" is a very important attribute that determines the appearance of each cultural region. According to Alfred Kroeber, the cultural region is closely related to the natural area; Cultural region is a defined geographical area, characterized by the similarity in most cultural features. In general, a cultural area is often defined as a geographical area in

\footnotetext{
${ }^{2}$ According to Prof. Tran Ngoc Them: "Culture is an organic system of human and material values created and accumulated through practical activities, in the interaction between people and natural and social environment". Source: (Tran Ngoc Them, Vietnamese Cultural Facility, Education Publishing House, p.10)
} 
which different communities have similar cultural characteristics, have the same type of mode of operation, or the same orientation. mainstream culture the same. For example: East Africa breeding culture region, Central American maize culture area [Nguyen Ba Thanh, 2006, p.381].

In the Southwest, the people live mainly on agriculture, especially rice cultivation, production and processing of rice products, so they carry their own nuances called "rice culture". After rice, the leading product representing the Southwest, is a fruit product called "fruit culture"; Among the hundreds of fruits, the most typical one is coconut [Tran Ngoc Them, 2013]. This fruit is not only a symbol for Ben Tre province but also for the Southwest and the South.

Due to living conditions with a special natural environment in the lower Mekong region, the people of Ben Tre took coconut farming (gardening) and exploitation and processing of coconut products, along with the exploitation and processing of resources on the river, is the main source of livelihood. Therefore, when we consider these characteristic production activities of the people living in the coconut - water river, we will identify cultural identity as well as some nuanced nuances of their garden through activity production labor.[5], [6].

\section{Coconut farming in Ben Tre, a special and intriguing garden civilization}

Ben Tre exiles began to explore the area of the sea islet in the 17th century, at first people chose high lands (mainly mounds or mounds), with little fresh water and little climate. more toxic jungle region to live, explore the natural improvement is seen as part of the resident subregion p scare sa sweet [7].

Initially, the Vietnamese who settled here were inevitably act out of habit and experience the traditional farmer's North B o and the B in rice cultivation. According to a field survey of Nguyen Chi Ben: "the elders in Dinh Thuy (Mo Cay, Ben Tre) remember that in the early twentieth century, this area was still cultivating wet rice. more than 50 years ago" [Nguyễn Bá Thành, 2006, p. 434]. Because the actual living conditions have helped them realize that this land has many rivers, many canals and the salinity fluctuates with the seasons, the selection of coconut trees, a tree specially adapted to brackish areas, is a the choice is very suitable to the environment here. Unlike the people who grow rice or fish, aquaculture, coconut farmers in Ben Tre have a very specific production culture is shown in the following aspects.

Up the planting coconut is a solution to turn lowland forests into an ideal environment to grow coconuts. The raised beds have the effect of raising the topsoil, change alum and enhance the thickness of the layer of arable land to avoid flooding during the rainy season.

The digging of a ditch on a coconut plantation can be said to be one of the unique behaviors of the people of Ben Tre with their living environment. The trench has many effects such as lowering the alkaline soil, bringing fresh water to irrigate, alluvium increases soil fertility, RU a acidity to the soil, drainage helps avoid flooding... They took advantage Use this method to create a favorable environment for coconut trees to live and grow, to facilitate irrigation, harvesting and aquaculture in parallel with coconut cultivation. Thanks to the ditch system plus the semi-diurnal tide regime of the rivers and canals of coconut, people can get heavy silt of silt to nurture the green trees. And thanks to the ditch system, people can "drive" to the port easily after harvesting the coconut. 

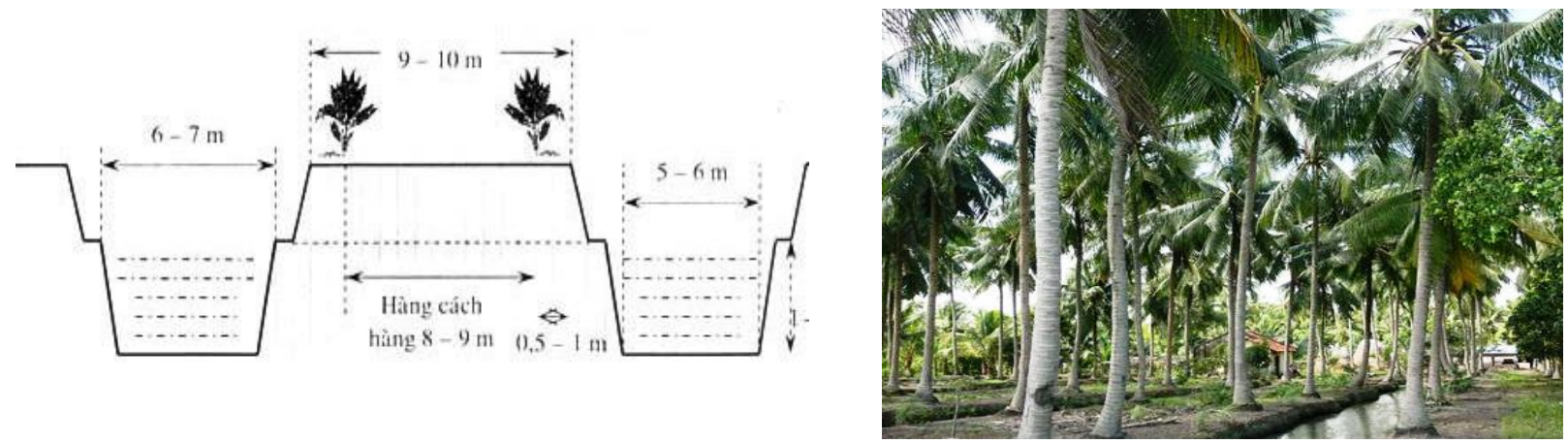

Figure 2. Sketch of a row of coconuts in the middle of a double tree (Image source: Website of People's Committee of Ben Tre)

The history of Ben Tre has been associated with the excavations to form the coconut forest today. In the beginning, when coconut handshake started with the ancient residents, it was possible to carefully measure the distance, distance, frequency and density, then mark and then put tissues in the places. specified. Tissue usually has a diameter of about $1 \mathrm{~m}$, the distance between the tissues ranges from $7-8 \mathrm{~m}$ is just enough for coconut to grow well. Between the coconut tissue can still grow, intercropping of short-term crops until maturity (about 3-5 years). Between the coconut is the ditch through the canals $\mathrm{p}$ scare sa follow that accreting into the ditch. People take alluvium on coconut tissue. Each year, the coconut tissue is taller and wider, giving the coconut enough land to grow [according to data compiled from the provincial website].

About three or four years later, when the coconut is about to come out with a cat's tongue (buds), people dug deep ditches to get the soil back and join the tissues to connect along the longitudinal lines that were intended to form the banks. a coconut garden. On the banks of the land, people continue to grow short-term crops intercropped with coconut trees such as papaya, chili, tomato, cucumber... Fertilizers, water for crops are also applied to coconut trees.

Nowadays, walking in coconut forest, no one can imagine the new coconut planting day. It takes years of alluvial accretion to turn a low field into a coconut garden. Thanks to the canal system, alluvium can enter every corner of the garden. Before the net tide has a period of standing water, it is time for the sediment to settle before the water recedes in preparation for a new cycle. When the water is big, bags of rubbish and insects will be washed away and fresh water washed with alum will make the coconut garden greener every day. Therefore, the area of coconut in Ben Tre increases each year and this place is called Made Coconut because it has the highest area and production of coconut in the country. And coconut has become a typical specialty and the pride of the people of Ben Tre.

\section{Coconut farming in Ben Tre in the context of climate change (CC) today}

\subsection{Weather losses often}

From the "adaptation to the environment" due to the "man-made process of cultural transformation" created by the authors' cultural ecology approach, we will find out why The current situation of climate change in the Lower Mekong - this area of Ben Tre is worrying. It can be said that, for thousands of years, humans have lived quite balanced with the natural environment, they have discovered, exploited and exploited nature in the capacity of natural 
regeneration. But only in the last 2-3 centuries has the environmental problem suddenly become markedly dangerous due to the excessive destruction of mankind.

In particular, never before did the world we live in change as quickly as in recent decades, mainly due to the impact of technology development, population growth and children's consciousness. person (or in other words it is "human ear") not less impact to the rapid changes of the process of climate change, human dependence on technology (clearance commissioner habitat by dad he makes up).

Along with the increasingly harsh impacts of climate change due to the disruption of the natural balance is manifested by the anomalies. The dry season starts from November to April next year, during which time the prolonged heat waves usually occur from January to April, in which March and April are the months with very high temperatures during the day. and salinity drought culminates, seriously affecting production activities of people in the province, especially districts near the sea.

Table 4.1. Extreme weather events often occur in the province

\begin{tabular}{|l|l|l|l|l|l|l|l|l|l|l|l|l|}
\hline Acting event (month) & $\mathbf{1}$ & $\mathbf{2}$ & $\mathbf{3}$ & $\mathbf{4}$ & $\mathbf{5}$ & $\mathbf{6}$ & $\mathbf{7}$ & $\mathbf{8}$ & $\mathbf{9}$ & $\mathbf{1 0}$ & $\mathbf{1 1}$ & $\mathbf{1 2}$ \\
\hline Dry season & $\mathrm{X}$ & $\mathrm{X}$ & $\mathrm{X}$ & $\mathrm{X}$ & & & & & & & $\mathrm{X}$ & $\mathrm{X}$ \\
\hline Drought & & & $\mathrm{X}$ & $\mathrm{X}$ & & & & & & & & \\
\hline Unexpected rain & $\mathrm{X}$ & & & $\mathrm{X}$ & & & & & & & & \\
\hline Rainy season & & & & & $\mathrm{X}$ & $\mathrm{X}$ & $\mathrm{X}$ & $\mathrm{X}$ & $\mathrm{X}$ & $\mathrm{X}$ & & \\
\hline Term she grated & & & & & & & & $\mathrm{X}$ & & & & \\
\hline Low pressure, storm & & & & & & & & $\mathrm{X}$ & $\mathrm{X}$ & $\mathrm{X}$ & $\mathrm{X}$ & $\mathrm{X}$ \\
\hline Tides & $\mathrm{X}$ & & & & & & & & $\mathrm{X}$ & $\mathrm{X}$ & $\mathrm{X}$ & $\mathrm{X}$ \\
\hline Landslide & & & & & & & & $\mathrm{X}$ & $\mathrm{X}$ & $\mathrm{X}$ & $\mathrm{X}$ & $\mathrm{X}$ \\
\hline Tornado & & & & & & & & $\mathrm{X}$ & $\mathrm{X}$ & $\mathrm{X}$ & $\mathrm{X}$ & \\
\hline
\end{tabular}

(Source: In-depth interviews with farmers of the research team)

In addition to the prolonged drought in the dry season, the locality also suffers from drought $^{3}$. This is a drought that occurs in the rainy season, usually occurs in August every year, when the Southeast monsoon encroaches to repel the wind from the West wind, causing continuous droughts, each lasting from 5 to 7 days., sometimes up to 15 days. Droughts can cause river water to exhaust, causing water shortages for irrigation, reducing crop yields. The unseasonal rain usually occurs in January or April every year. This is the time when the trees grow quite green or approaching harvest time, causing significant impact to production activities of households people here, especially the household see to ng coconut.

The rainy season usually starts from May to October, during this period, tropical depression, storms often occur in August, September, October and November, causing heavy rain. Storm surge takes place from September to January next year, causing local flooding in some places. Landslides occur frequently, especially in estuaries and coastal areas from August to December each year. Tornadoes occur between August and November each year. All these extreme weather events combined with strong winds every year cause serious damage to production activities and daily life here.

\footnotetext{
${ }^{3}$ The main livelihood model in a year is the household production and business models that people spend the most time in a year to generate income (as defined by the authors).
} 
With what is happening, there will no longer be a "paradigm of culture" of people fit into a natural environment in the context of climate change today. So, which rolls native is "the way in which the process of cultural change will be consistent with the natural environment " can help people adapt better to the environment e waterlogged means, than an environment artificial. It is a process of reciprocity, which means that environmental impact on the lives of people whereas humans also have a huge impact on the environment through the medium which the authors called e ó is cultural ecology in dealing with nature.

The community here with its inherent indigenous forms has created effective and sustainable solutions such as: digging a pond to store rainwater for garden irrigation; store water in jars for daily use; planting coconuts on sand dunes; optimize the VAC model (garden, pond, barn), grow fish sauce, cork, grow nipa palm to prevent erosion, etc. Especially, coconut tree silhouette always appears in these models with different frequencies such as: while the farmers have planted coconut as the main livelihood, or sometimes just to keep the dike, preventing saline nhậ p, soil retention, three shore, shaded... The planting of coconut trees to prevent salinity and erosion of saline and brackish areas has shown the people's behavioral culture with the natural environment effectively, clearly demonstrating the nature of using natural remedies. course. These are ways to demonstrate environmentally friendly behavior, with a sense of respect for and protection of natural resources.

\section{2. Analysis of a number of key household livelihood models ${ }^{4}$}

The authors have participated in a survey of 59/164 communes in Ben Tre province, mainly in the districts adjacent to the sea (brackish and salt water) although the area and production of coconut trees are not strong. here but the majority of households have converted to huge coconut plantation by the adaptation of climate, soil and hydrology as well as investment costs long-term stability than the type of plants and other animals.

Table 4. 2. Some main livelihood models

\begin{tabular}{|c|c|c|c|c|c|c|c|}
\hline \multicolumn{2}{|c|}{$\begin{array}{l}\text { Some main livelihood models } \\
\text { (MHSK) [Unit: Vietnam Dong] }\end{array}$} & Symbol & $\begin{array}{c}\text { Total } \\
\text { income }\end{array}$ & Spend & Saving & $\begin{array}{l}\text { Income } \\
\text { over } 1 \\
\text { ha }\end{array}$ & Evaluate $^{5}$ \\
\hline Fruit tree & $\begin{array}{l}\text { Mango, orange, } \\
\text { grapefruit }\end{array}$ & (first) & 130,667 & 84,333 & 36,333 & 7,409 & Rather \\
\hline Planting color & $\begin{array}{l}\text { Watermelon / } \\
\text { Beans / Cassava }\end{array}$ & (2) & 65,478 & 51,387 & 14,091 & 26,290 & Good \\
\hline Breeding combined & $\begin{array}{l}\text { Raising pigs / } \\
\text { chickens and } \\
\text { ducks combined } \\
\text { with crops }\end{array}$ & (3) & 439,267 & 397,600 & 41,667 & 7,409 & Rather \\
\hline \multicolumn{2}{|c|}{$\begin{array}{l}\text { Breeding + planting coconut } \\
\text { combined }\end{array}$} & (4) & 140,667 & 94,333 & 46,333 & 17,409 & Good \\
\hline \multirow[b]{3}{*}{ Aquaculture } & Whiteleg shrimp & (5a) & 721,659 & 492,235 & 229,424 & 106,675 & medium \\
\hline & $\begin{array}{l}\text { Extensive black } \\
\text { tiger shrimp }\end{array}$ & (5b) & 66,786 & 46,879 & 19,907 & 5,901 & medium \\
\hline & Shrimp, crab + & $(5 c)$ & 139,737 & 101,1139 & 38,598 & 19,017 & Good \\
\hline
\end{tabular}

\footnotetext{
${ }^{4}$ The main livelihood model in a year is the household production and business models that people spend the most time in a year to generate income (as defined by the authors).

${ }^{5}$ Evaluate drivers in 5 categories: 1 . Urgency, 2. Stability, 3. Integrity, 4. Feasibility (cost), 5. Sustainability .
} 


\begin{tabular}{|l|l|c|c|c|c|c|c|}
\hline & forest farming & & & & & & \\
\cline { 2 - 7 } & $\begin{array}{l}\text { Aquaculture }+ \\
\text { salt }\end{array}$ & $(5 \mathrm{~d})$ & 25,900 & 22,125 & 3,775 & 13,169 & Rather \\
\cline { 2 - 7 } & $\begin{array}{l}\text { Breeding } \\
\text { oysters / clams }\end{array}$ & $(5 \mathrm{e})$ & 116,659 & 84,214 & 32,286 & 56,971 & medium \\
\hline
\end{tabular}

(Source: Calculated results of the research team)

Based on criteria, use data to collect income and expenditure information from livelihood models over the years. Through analysis based on the value of net income of households and families, and combined with the criteria of sustainable development on the environment as adaptability to climate change coastal areas to assess the level of sustainability and efficiency of a Model number follows:

* Shrimp/crab intercropping forest model (MHSK 5c): Afforestation / intercropping with shrimp/crab intercropping is a good model, providing stable income, low risks and environmental friendliness. Sustainable aquaculture development model, aquaculture combined with afforestation. In the context of increasingly polluted water, making aquaculture face many disadvantages, sustainable and environmentally friendly aquaculture is a goal to be developed and oriented in the future. Besides the aquatic species that are stocked in ponds, shrimp, crabs are also released into the natural environment around the aquaculture areas of the people. Mangroves are planted and protected to contribute to landslide control, climate control, and environmental protection for a large area and at the same time provide shelter and development for aquatic and marine species.

* Model of crops on sand dune (MHSK 2): All year round for stable income, lack of fresh water, saline intrusion is no longer a concern of the people. Because the low-lying land is less affected, choosing good crops will bring high efficiency. The model of intercrop rotation in agricultural cultivation should be encouraged to be replicated because the advantage of this model is soil improvement, avoiding the spread of diseases on crops, especially her crop production. children of coastal communes of the province. For example, planting melon-covered melon contributes to saving irrigation water, on the other hand, it reduces weeds, prevents soil erosion and helps prevent pests. The model of planting watermelon on canvas is favored by farmers because of its economic efficiency and suitability to local lands.

* Model livestock combined coconut (MHSK 4): is a method of diversifying livelihoods and income for coastal communities that utilize the facilities inherent in each family and apply ways of production new production such as renovating the mixed garden into a special garden (planting coconut), intercropping elephant grass, raising cows on the goats, goats and fish ponds (catfish, grass carp...). This land is actually a cage garden model (VAC), but this model is not new, but it shows the advantages of a subsistence micro-ecological system, which is very suitable in the current practical situation. The preeminent feature of this model is its resilience and rapid recovery in the context of climate change, easy to apply at the household level, providing effective direct impact on people's lives.

Moreover, it is not difficult to apply the above model, using local experience/indigenous knowledge mainly in dealing with the natural environment and adapting to climate change. The model has high flexibility through the conversion of livestock and crop structure suitable to climate change. It can be said that VAC is a sustainable livelihood model, ensuring 
environmental friendly factors and diversifying agricultural products, capable of replicating in all regions.
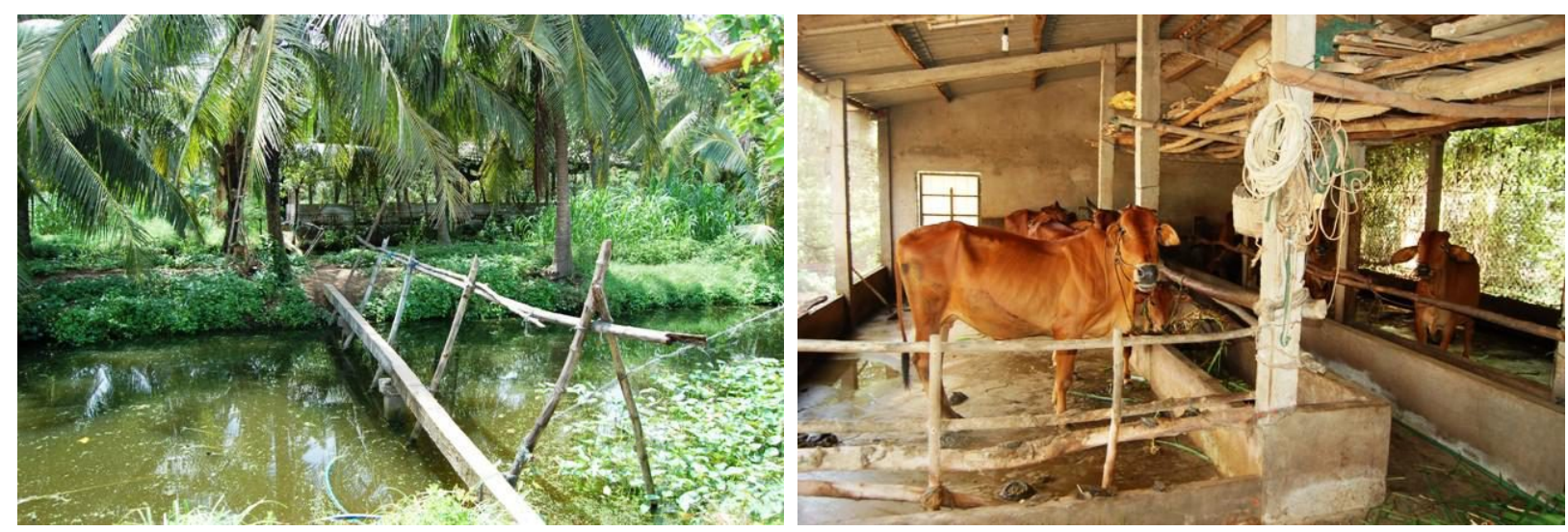

Figure 3. Circular pattern g coconut combined breeding in Ba Tri (Figure from Dai-Long)

ince then, it is realized that the livelihood models of the people here are actually the household production and business models that people spend the most time in a year to generate income. In particular, the model is considered as the most effective (e Assessment Good) always have a combination of three elements: economic, social and environmental. These models generate profits, towards the quality of life of environmentally friendly communities, if these 3 elements reach equilibrium, they will satisfy sustainability. Each region of Ben Tre has the optimal models suitable for each locality.

However, according to the author of the research group in Ben Tre, the "model of coconut farming combined with livestock" (MHSK4) is considered to be quite suitable for households and cultural characteristics of the villagers. address here. Because of the relatively rapid adaptation of coconut trees in the context of climate change, when the annual area of salt water from the sea continues to penetrate deep into the mainland, some areas are exposed to great salinity, combining heat. Despite increasing in recent years, coconut trees still increase in both area and yield.

\section{Evaluation of integrated coconut (MHSK4) model in the context of climate change}

In the local livelihood models are applied, all contribute to solving environmental issues, landscape ecology and ensuring fresh air, water in the locality. It is easy to see that in the last 05 years, the area of regenerated coconut gardens and coconut forests has gradually greened on the islets and dunes in the area. Therefore, it can be seen that coconut cultivation is a form of farming with green economic value, contributing to the rational use of land resources effectively.

Thanks to the diversification of livelihood models, the coconut farming model has contributed significantly to social and cultural issues. The most obvious effect is to create jobs for local people, both to create conditions for increasing incomes for farmers, initial investment costs are not expensive... Rural life has stabilized, the percentage of poor households has decreased markedly, the rich-poor gap has been narrowed in the area.

Therefore, it is possible to draw some remarks from the model as follows: 
- In terms of area: MHSK4 model does not need a large area of 2 or more land, it can promote the effectiveness of the model. While the remaining four models are applicable to very large land sizes.

- In terms of distribution location: the MHSK4 model is often distributed where the terrain is mound, sandy loam, along the rivers, where is flat, resistant to brackish and salinity while the remaining models are distributed mainly. Weak in dunes, mangroves.

- In terms of human resources: MHSK4 model does not require a lot of labor, participating households can do it themselves, do not require much technically, the number of regular workers is not much and does not need to attract numbers A large amount of labor is available in the seasons. While the remaining four models do not require a lot of regular labor, they can hire seasonally.

- In terms of investment capital: MHSK4 model does not need a large capital investment compared to the remaining models. In addition, this model is very adaptive in the context of changes when the direction of salt water increases.

- Considering the level of risk: MHSK4 is the model that has the lowest risk level because of the high initiative of the farmer and the continuous farming method, supporting each other between ponds, coconut gardens, barn and planting combined colors. Breeding provides fertilizer for the coconut garden. Coconut gardens both produce products with high economic returns and contribute to keeping the soil and water for the model, and can be intercropped with short-term crops.

Thus, coconut planting combinations (MHSK4) is a model of economical eco-green, fairly stable, helping people self-improvement cultivation practices, consistent with the characteristics typical of natural, climatic, rivers and land in the locality, gradually raising productivity and output. Therefore, it is possible to transform the coconut economy from a household nature to a cooperative or a farm based on a high-quality ecological agriculture model.

\section{Conclusions and recommendations}

In the current integration trend, especially after our country has joined the WTO, Ben Tre has many conditions to promote the export advantage of coconut products, helping thousands of households to stabilize their lives and increase incomes., poverty reduction. However, ash ng context of climate change as the model current "Good", while point should focus on irrigation, agriculture, plant protection... along with programs to encourage coconut plantation, issued preferential policies for investors investing in the processing of coconut products. In particular, it is necessary to consider raising the province's specific strength, which is coconut economy. It is thought that in the coming time, Ben Tre province should have some policies to manage, exploit and promote more cultural values from the community living with coconut trees for more than 300 years, as follows:

- Planning and construction of "space ecological culture Coconut" into a tourist destination - a tourist products characteristic of the province, a Festival stature q Convention including international activities such as: Contest "The Beauty of Coconut", the "Coconut Food Festival ", linking eco-friendly tours to the community, exhibitions to honor individuals in socio-economic activities attached to coconut tree. Especially artisans, craftsmen, farmers have devoted themselves to coconut trees, helping generations to understand and promote the 
values from coconut trees. It is a place that combines $\mathrm{h}$ Ai harmony between nature, human and cultural values from coconut trees bring.

- Identify coconut trees as strategic industrial plants - agriculture of the province as well as of the country in particular. From there, coconut growers will see the true meaning and benefits, contributing to increasing the value chain of local coconut trees, especially in the context of climate change today. Special, $t$ while point should create favorable conditions for planting coconut, coconut growing area are expanding.

- Further promote the role of the "Four Heads - link 04 home" of the association, group and organizations at home and abroad about Cay Dua. In this way, coconut growers (farmers) and entrepreneurs as well as the State and associated scientists maximize the value brought by coconut trees. In particular, for coconut growers to see it as a career, should have a policy to support seedlings for farmers, so coconut cultivation really brings an economic, cultural and ecological significance to the community residents of $\mathrm{Xu}$ Dua - Ben Tre.

\section{References}

1. Joralemon, David 2010, "Exploring Medical Anthropology", Upper Saddle River. NJ: Prentice Hall.

2. Nguyen Thanh Thanh 2006, "Vietnamese identity through literary exchange", Hanoi National Publishing House.

3. Decision No. 2300 / QD-UBND Ben Tre on the program to develop coconut industry in Ben Tre province to 2020

4. Tran Ngoc Them, 2013, "Vietnamese culture in the Southwest region", Publisher. VHNT.

5. Sea and Island Research Center 201 3, "Coping with saline intrusion and flooding of communities in three coastal districts of Ben Tre province - Situation and solutions", Code: B2011-18b - 11, VNU-HCM.

6. Steward, Julian 1955, "Theory of Culture Change: The Methodology of Multilinear Evolution", Urbana: University of Illinois Press.

7. Le, T., Ngo, L., \& Nguyen, T. (2014). Islands and archipelagos of Vietnam in the East sea in the process of economic - social development and national security defense. Science and Technology Development Journal, 17(1), 114-128.

8. http://www.imh.ac.vn/b tintuc sukien/dc hoinghi hoithao/L555thuтиссиoi/mlfolder.2007-04-13.0236405440/40\%20Thi\%20305.pdf, accessed on July 1, 2014, article "Some economic model adapting to climate change in Ben Tre and Ninh Thuan".

9. http://www.bentre.gov.vn/content/section/6/46/, accessed July 1, 2014.

10. $\quad$ http://hiephoiduabentre.com.vn/index.php? Module $=$ Content \&Action=view\&id=3 839, accessed July 2, 2014, article "Biological characteristics of Ben Tre coconut tree".

10. http://hiephoiduavietnam.org/tin-tuc/6/39/453/nghe-trong-dua-o-ben-tre---mot-sac-thaivan-minh-nong-nghiep-dac- biet.html, accessed July 3, 2014, article "A special nuance of agricultural civilization". 